\title{
Hyperthyroidism and production of precocious involution in the mammary glands of lactating rats
}

\author{
S. M. Varas ${ }^{1}$, E. M. Muñoz², M. B. Hapon³, \\ C. I. Aguilera Merlo ${ }^{2}$, M. S. Giménez ${ }^{1}$ and G. A. Jahn ${ }^{3 *}$ \\ ${ }^{1}$ Laboratorio de Bioquímica Molecular and ${ }^{2}$ Laboratorio de Histología y Embriología, \\ Departamento de Bioquímica y Ciencias Biológicas, Facultad de Química, \\ Bioquímica y Farmacia, Universidad Nacional de San Luis, 5700 San Luis, Argentina; \\ and ${ }^{3}$ Laboratorio de Reproducción y Lactancia, IMBECU CRICYT-CONICET, \\ Casilla de Correos 855, 5500 Mendoza, Argentina
}

This study investigated the influence of chronic hyperthyroidism on mammary function in lactating rats and the effects on their pups. Thyroxine-treated $(10 \mu \mathrm{g}$ per $100 \mathrm{~g}$ body weight per day; hyperthyroid (HT)) or vehicle-treated rats were mated 2 weeks after the start of treatment and killed with their litters on days 7, 14 and 21 of lactation. Serum concentrations of triiodothyronine $\left(T_{3}\right)$ and tetraiodothyronine $\left(\mathrm{T}_{4}\right)$ increased in thyroxine-treated rats. In HT mothers, serum prolactin decreased on day 7 and day 14 of lactation, whereas insulin-like growth factor I (IGF-I) and progesterone concentrations decreased, and corticosterone increased on day 7 of lactation. In HT pups, $T_{4}$ concentration increased on day 7 and day 14 of lactation, whereas $T_{3}$ increased only on day 14 of lactation, and growth hormone increased on day 7 of lactation. Mammary prolactin binding sites did not vary, but there was an increase in the binding sites in the liver on day 14 of lactation in thyroxine-treated rats. In an acute suckling experiment, thyroxine-treated rats released less oxytocin, growth hormone and prolactin and excreted less milk than did control rats. Mammary casein, lactose and total lipid concentrations in thyroxine-treated rats were similar to those of control rats on day 14 of lactation. Histological studies of the mammary glands showed an increased proportion of alveoli showing reduced or no lumina and cells with condensed nuclei on day 14 and day 21 of lactation; the TdT-mediated dUTP nick-end labelling (TUNEL) test revealed an increase in apoptosis in alveolar cells on day 21 of lactation in thyroxine-treated rats. Expression of SGP-2, a gene expressed during mammary involution, increased in thyroxine-treated rats on day 14 and day 21 of lactation, whereas expression of insulin-like growth factor binding protein 5 , a proapoptotic signal, was unchanged. Bcl-2, which promotes survival of mammary gland epithelial cells was unchanged, whereas expression of IGF-I, which also promotes survival of mammary gland epithelial cells, increased on day 21 of lactation in thyroxine-treated rats. These results indicate that thyroxine treatment produces some milk stasis as a result of impairments in suckling induced release of oxytocin that may initiate the first stage of mammary involution, increasing apoptosis in a gland that is otherwise actively producing and secreting milk.

\section{Introduction}

Two per 1000 pregnant women have some degree of hyperthyroidism (HT). Most of the symptoms of HT are attenuated during pregnancy, but there is a marked recurrence of HT after delivery, which has an adverse effect on development of the offspring (Rodin and Rodin, 1989). Rosato et al. (1992a, 1998) showed that the chronic administration of tetraiodothyronine $\left(\mathrm{T}_{4}\right)(100 \mu \mathrm{g}$ or $25 \mu \mathrm{g} \mathrm{T}$ per $100 \mathrm{~g}$ body weight) to rats advanced birth and lactogenesis, and had adverse effects on maternal behaviour and milk ejection, which resulted in death of the pups. Histological studies of the mammary gland at term showed functional

*Correspondence

Email: gjahn@lab.cricy.edu.ar or svaras@unsl.edu.ar mammary tissue, with signs of full lactogenesis (the alveolar lumina completely filled with secretion) and almost total absence of adipose tissue (Rosato et al., 1992b). Varas et al. (2001) reported that the chronic administration of $<10 \mu \mathrm{g}$ $\mathrm{T}_{4}$ per $100 \mathrm{~g}$ body weight to lactating rats produces important changes in lipid metabolism in liver and mammary gland on days 7, 14 and 21 of lactation. In addition, the growth rate of the litters was adversely affected.

Proliferation and differentiation of mammary gland epithelial cells are under stringent hormonal control. In mature virgin females, the epithelial cell population is a minor part of the mammary gland, which is composed mainly of adipose stromal tissue. Pregnancy induces massive development of the epithelium resulting in full differentiation and postpartum milk production. This proliferation of the epithelial cells is accompanied by a 
relative loss in adipose cell volume. During lactation most of the mammary gland volume is attributable to secretory acini, and there is an increase in size of epithelial cells and distention of alveoli due to accumulation of secretory material within their lumina (Imagawa et al., 1994). After weaning, the mammary gland regresses; the secretory epithelium undergoes apoptosis; and the adipose stroma resumes lipid storage. Quarrie et al. (1996) showed that apoptosis in the mammary gland contributes to natural as well as enforced mammary involution and that milk stasis may, in part, promote the induction of apoptosis during weaning. In addition, the initial phase of involution is characterized by induction of the apoptosis-associated gene SGP-2 (also known as clusterin or TRPM-2) and apoptosis of fully differentiated epithelial cells (Lund et al., 1996). Tonner et al. (1997) reported that insulin-like growth factor binding protein 5 (IGFBP5) could play a key role in the involution process increasing the binding of insulin-like growth factor I (IGF-I), a known promoter of mammary epithelial cell survival (Travers et al., 1996). Finally, Bcl-2 prevents apoptosis; and Schorr et al. (1999) reported that $\mathrm{Bcl}-2$ increased mammary epithelial cell survival during the first apoptotic stage of involution in transgenic mice.

The aims of the present study were to examine the effects of hyperthyroidism during lactation on circulating concentrations of some of the hormones involved in mammary function, including, prolactin, growth hormone, IGF-I, progesterone and corticosterone, and to analyse the function and observe histology of the mammary gland of hyperthyroid dams. In addition, the expression of several proteins associated with the control of mammary involution, such as SGP-2, Bcl-2, IGF-I and IGFBP-5, was measured.

\section{Materials and Methods}

\section{Chemicals}

L-Tetraiodothyronine $\left(\mathrm{T}_{4}\right)$ was a generous gift from Glaxo (Buenos Aires). All the other chemicals were of reagent grade and were obtained from Merck Laboratory (Buenos Aires).

\section{Animals and experimental design}

Adult female Wistar rats bred in our laboratory were 3-4 months old and weighed about $200 \mathrm{~g}$ at the onset of treatment. The rats were kept in a controlled environment at $22-25^{\circ} \mathrm{C}$ with a $12 \mathrm{~h}$ light: $12 \mathrm{~h}$ dark photoperiod. Rat chow and tap water were available ad libitum. Animal maintenance and handling were performed according to the $\mathrm{NIH}$ Guide for the Care and Use of Laboratory Animals (NIH publication No 86-23, revised 1985 and 1991) and the UK requirements for ethics of animal experimentation (Animals (Scientific Procedures) Act 1986).

Hyperthyroidism was induced by daily s.c. injection of $10 \mu \mathrm{g} \mathrm{T}_{4}$ per $100 \mathrm{~g}$ body weight. $\mathrm{T}_{4}$ was dissolved in $0.9 \%$ $(\mathrm{w} / \mathrm{v}) \mathrm{NaCl}$ and $\mathrm{NaOH}$ was added to $\mathrm{pH}$ 9. The presence of spermatozoa in the vaginal smear on the morning after the pro-oestrous female was caged with a fertile male indicated pregnancy and was designated as day 0 of pregnancy. Thyroxine- or vehicle-treated rats became pregnant approximately 14 days after treatment started and were killed by decapitation at 09:00-10:00 $\mathrm{h}$ on days 7, 14 and 21 of lactation. The rats were injected with thyroxine or vehicle during weeks 6,7 and 8 (days 7, 14 and 21 of lactation, respectively).

On day 1 of lactation, the litters were allocated randomly to groups to eliminate any individual maternal effects during pregnancy on the subsequent lactational performance, and the number of pups in each litter was standardized to eight.

Blood samples were collected from dams and their pups and serum was separated by centrifugation at $600 \mathrm{~g}$ for $15 \mathrm{~min}$ and stored at $-20^{\circ} \mathrm{C}$ until use. The livers from dams and their pups and inguinal mammary glands from dams were removed, washed in a cold saline solution and stored at $-70^{\circ} \mathrm{C}$ until they were analysed. Blood samples and tissues of the pups were pooled for each litter and thus the values represent the mean values for the litters. The body weight of the pups is the mean \pm SEM for eight litters.

\section{Hormone determinations}

Total serum concentrations of $\mathrm{T}_{3}$ and $\mathrm{T}_{4}$ were determined by a commercial ELISA kit (Boehringer Mannheim Argentina, Buenos Aires). IGF-I and corticosterone in sera were measured by radioimmunoassay using commercial kits for total hormone (DSL total rat IGF-I radioimmunoassay DSL-2900 and rat corticosterone DSL-10-81100 double antibody radioimmunoassay; Diagnostic Products Corp., Los Angeles, CA).

Prolactin and growth hormone $(\mathrm{GH})$ concentrations were measured by double antibody radioimmunoassay using materials generously provided by the National Hormone and Pituitary Program (NHPP) (NIADDK). The hormones were radio-iodinated using the chloramine $\mathrm{T}$ method and purified by passage through Sephadex G75. The results are expressed in terms of the rat prolactin 3 (RP-3) or rat GH (RP-2) standard preparation. Assay sensitivity was $0.5 \mu \mathrm{g}$ serum $\mathrm{I}^{-1}$ and the inter- and intra-assay coefficients of variation were $<10 \%$ for both hormones.

Oxytocin was measured by double antibody radioimmunoassay using an antibody and purified oxytocin generously provided by N. Hagino (University of Texas Health Center, San Antonio, TX) and Novartis (Buenos Aires), respectively. Oxytocin was radio-iodinated using the Chloramine $\mathrm{T}$ method and purified by passage through Sephadex G50. The standard curve was prepared using the preparation of purified oxytocin used for radio-iodination. The sensitvity of the assay was maximised by incubating the standards and serum samples for $24 \mathrm{~h}$ with an appropriate dilution of the antibody, and subsequently the labelled hormone $\left(8-10 \times 10^{3}\right.$ c.p.m.) was added and the tubes were incubated overnight before addition of the second antibody. Assay sensitivity was $8 \mathrm{ng} \mathrm{l}^{-1}$ serum, and the interand intra-assay coefficients of variation were $<10 \%$. 
Serum progesterone was measured using a radioimmunoassay developed by Bussmann and Deis (1979) with an antiserum raised in rabbits against progesterone-11-BSA conjugate. Assay sensitivity was $<70$ fmol per tube and the inter- and intra-assay coefficients of variation were $<10 \%$.

\section{Determination of casein, lactose and total lipids}

Casein and lactose in mammary glands were measured as described by Jahn and Deis (1991). In brief, $200 \mathrm{mg}$ mammary tissue was cut into small pieces and homogenized in $2 \mathrm{ml}$ of $50 \mathrm{mmol}$ sodium PBS I-1, $150 \mathrm{mmol}$ $\mathrm{NaCl} \mathrm{I}^{-1}, 0.1 \%(\mathrm{w} / \mathrm{v}) \mathrm{NaN}_{3}$ and $0.1 \%(\mathrm{v} / \mathrm{v})$ Triton-X100, $\mathrm{pH}$ 7.6 using an Ultraturrax homogenizer. The homogenate was centrifuged at $600 \mathrm{~g}$ for $30 \mathrm{~min}$ and the supernatant used for determination of $\beta$-casein by a homologous radioimmunoassay according to Edery et al. (1984), as modified by Bussmann and Deis (1984). Lactose concentrations were assessed by the method of Kuhn and Lowenstein (1967).

The total lipids of the mammary tissue were extracted with chloroform: methanol $(2: 1)$ according to the method of Folch et al. (1968).

\section{Membrane preparation}

Membranes were prepared from the mammary gland and the liver by homogenization of tissues in five volumes of $0.3 \mathrm{~mol}$ sucrose $\mathrm{I}^{-1}$ and centrifugation at $1500 \mathrm{~g}$ for $15 \mathrm{~min}$. Supernatants were centrifuged at $100000 \mathrm{~g}$ for $90 \mathrm{~min}$ to obtain crude membrane pellets, which were resuspended in two volumes of $25 \mathrm{mmol}$ Tris- $\mathrm{HCl} \mathrm{I}^{-1}(\mathrm{pH}$ 7) and $10 \mathrm{mmol}$ $\mathrm{MgCl}_{2} \mathrm{I}^{-1}$ (Katoh et al., 1987). These preparations were frozen at $-20^{\circ} \mathrm{C}$ until measurement of membrane binding using ${ }^{125} \mathrm{I}$-labelled ovine prolactin or ${ }^{125} \mathrm{I}$-labelled ovine growth hormone. Protein concentration was measured by the method of Lowry et al. (1951).

\section{Determination of prolactin and GH receptors}

Prolactin receptors and growth hormone receptors were determined by overnight incubation of $25 \mu \mathrm{g}$ (for liver samples) or $200 \mu \mathrm{g}$ (for mammary gland samples) of membrane protein with 130000 d.p.m. of ${ }^{125}$ I-labelled ovine prolactin, in a final volume of $0.5 \mathrm{ml}$ of $25 \mathrm{mmol}$ Tris- $\mathrm{HCl} \mathrm{I}{ }^{-1}\left(\mathrm{pH} \mathrm{7)}, 10 \mathrm{mmol} \mathrm{CaCl}_{2} \mathrm{I}^{-1}, 0.01 \% \mathrm{NaN}_{3}\right.$ and $0.2 \%(\mathrm{w} / \mathrm{v}) \mathrm{BSA}$ in the presence or absence of $1 \mu \mathrm{g}$ unlabelled ligand for measurement of specific or nonspecific binding. Incubations were stopped by the addition of $3 \mathrm{ml}$ ice-cold buffer; the membranes were separated by centrifugation at $600 \mathrm{~g}$ for $30 \mathrm{~min}$ and the radioactivity in the pellets determined using a gamma counter. The number of receptors was expressed as d.p.m. $\mathrm{mg}^{-1}$ protein. The hormones were labelled using the chloramine $\mathrm{T}$ method and separated from free iodine by passage through a column of ACA 54 (Pharmacia LKB, Bromma). The specific activity obtained was $60-80 \mathrm{Ci} \mathrm{mmol}^{-1}$.

\section{Acute suckling experiment}

At 08:00 h on day 10 or day 11 of lactation, groups of control and thyroxine-treated mothers were isolated from their litters. At 16:00 h, the litters were weighed and reunited with their mother, and after 30 min of vigorous suckling, blood samples were collected under light ether anaesthesia from the tail vein of the mothers. The litters were weighed again. Serum was separated and stored at $-30^{\circ} \mathrm{C}$ for prolactin, growth hormone and oxytocin radioimmunoassays.

\section{Histology}

Mammary gland tissue was fixed in Bouin's solution, dehydrated in ethanol and embedded in paraffin wax. Sections of 3-5 $\mu \mathrm{m}$ were cut with a Reichert-Jung $\mathrm{Hn} 40$ microtome and stained with haematoxylin and eosin. Images were taken with a Zeiss Axioscp 2 light microscope fitted with a Sony CCD-IRIS/RGB video camera under $\times 100$ and $\times 400$ magnifications. For all the morphological analyses, only the inguinal mammary glands were used. Sections were evaluated histologically for secretory activity and for changes in supporting adipose tissue and alveolar cells, and for the extent of ducto-lobular luminal secretions (alveoli showing reduced or no luminal space). The physiological status of the alveoli was determined by analysing serial sections from three different animals per group.

\section{Detection of apoptotic nuclei}

Serial sections of mammary glands from thyroxine- and vehicle-treated dams at day 14 and day 21 of lactation were deparaffinized, rehydrated and incubated with $50 \mu \mathrm{l}$ proteinase $\mathrm{K}\left(20 \mu \mathrm{g}\right.$ proteinase $\mathrm{K} \mathrm{ml}^{-1}$ in $10 \mathrm{mmol}$ Tris- $\mathrm{HCl}$ $\mathrm{I}^{-1}, \mathrm{pH} 7.8$ ) for $30 \mathrm{~min}$ at $37^{\circ} \mathrm{C}$. Slides were then washed in PBS. Fragmented DNA in apoptotic cells was end-labelled with the terminal deoxynucleotide transferase-mediated dUTP nick-end labelling (TUNEL) reaction using an in situ Cell Death Detection Kit (cat No. 1684809, Boehringer Mannheim). Fluorescein-linked nucleotides incorporated into DNA breaks were analysed in a fluorescence microscope (Axiovert 100, Zeiss) provided with a Leica camera.

\section{$R N A$ isolation and $R T-P C R$ analysis}

Total RNA from the mammary glands was prepared using the guanidinium isothiocyanate-acid phenol method (Chomczynski and Sacchi, 1987), as modified by Puissant and Houdebine (1990). One to three micrograms of total RNA were reverse transcribed at $42^{\circ} \mathrm{C}$ using random hexamer primers and Moloney murine leukaemia virus reverse transcriptase (Life Technologies, Buenos Aires) in a $20 \mu \mathrm{l}$ reaction mixture. Five microlitres of the reverse transcription reaction mix was amplified with primers specific for rat $\mathrm{SGP}_{2}, \mathrm{Bcl}-2, \mathrm{IGFI}$ and BP5-IGF (Table 1). The $\mathrm{L}_{19}$ ribosomal protein gene was used as an internal control. All reactions were carried out for 35 cycles (except $\mathrm{Bcl}-2$, 40 cycles) and then terminated with a 5 min extension at 
Table 1. Primer sequences used in the PCR amplification of various cDNAs

\begin{tabular}{|c|c|c|c|c|}
\hline cDNA & Sense primer $\left(5^{\prime} \rightarrow 3^{\prime}\right)$ & Antisense primer $\left(5^{\prime} \rightarrow 3^{\prime}\right)$ & Gene bank accessions & $\begin{array}{c}\text { Size of amplified } \\
\text { product (bp) }\end{array}$ \\
\hline L19 & CGССААТGССААСТСТССТСА & TTCCGTCGGGCCAAGGTGTTC & J02650 & 120 \\
\hline SGP-2 & TACAGTTCCCGGATGTGGAT & CACGAGAGGGGACTTCTGAG & NM012679 & 402 \\
\hline $\mathrm{Bcl}-2$ & ATGGCGCAAGCCGGGAGAA & CTTGTGGCCCAGGTATGC & U34964 & 708 \\
\hline IGF-I & AAAATCAGCAGTCTTCCAAC & AGATCACAGCTCCGGAAGCA & D00698 & 299 \\
\hline IGF-BP5 & TTGCСТCAACGAAAAGAGC & AGAATCCTTTGCGGTCACA & NM012817 & 377 \\
\hline
\end{tabular}

Each combination of primers has specific cyclic parameters: SGP-2: $94^{\circ} \mathrm{C}, 1 \mathrm{~min} ; 58^{\circ} \mathrm{C}, 1 \mathrm{~min} ; 72^{\circ} \mathrm{C}, 1 \mathrm{~min} . \mathrm{Bcl}-2: 94^{\circ} \mathrm{C}, 1 \mathrm{~min} ; 55^{\circ} \mathrm{C}, 30 \mathrm{~s} ; 72^{\circ} \mathrm{C}, 2 \mathrm{~min}^{2}$ Insulin-like growth factor I (IGF-I) and insulin-like growth factor binding protein 5 (IGFBP5): $94^{\circ} \mathrm{C}, 1 \mathrm{~min} ; 53^{\circ} \mathrm{C}, 30 \mathrm{~s} ; 72^{\circ} \mathrm{C}, 1 \mathrm{~min}$.

Table 2. Effects of hyperthyroidism on serum hormone concentrations in lactating rats and their pups

\begin{tabular}{|c|c|c|c|c|c|c|}
\hline & \multicolumn{2}{|c|}{ Day 7 of lactation } & \multicolumn{2}{|c|}{ Day 14 of lactation } & \multicolumn{2}{|c|}{ Day 21 of lactation } \\
\hline & Control & $\mathrm{HT}$ & Control & $\mathrm{HT}$ & Control & $\mathrm{HT}$ \\
\hline \multicolumn{7}{|l|}{ Mothers: } \\
\hline $\mathrm{T}_{3}\left(\mathrm{ng} \mathrm{dl^{-1 }}\right)$ & $21.5 \pm 1.3$ & $31.0 \pm 3.8^{*}$ & $23.3 \pm 3.8$ & $38.5 \pm 2.1^{*}$ & $26.3 \pm 2.1$ & $44.7 \pm 4.6^{*}$ \\
\hline $\mathrm{T}_{4}\left(\mu \mathrm{g} \mathrm{dl^{-1 }}\right)$ & $5.9 \pm 0.1$ & $6.6 \pm 0.2^{*}$ & $6.0 \pm 0.3$ & $8.6 \pm 0.8^{*}$ & $6.3 \pm 0.3$ & $7.5 \pm 0.5^{*}$ \\
\hline Prolactin (ng ml-1) & $93.3 \pm 24.4$ & $42.9 \pm 9.2^{*}$ & $68.9 \pm 16.4$ & $12.3 \pm 4.3^{*}$ & $3.2 \pm 1.2$ & $3.0 \pm 0.6$ \\
\hline Growth hormone $\left(\mathrm{ng} \mathrm{ml}^{-1}\right)$ & $8.4 \pm 2.0$ & $7.4 \pm 3.2$ & $5.1 \pm 0.8$ & $5.3 \pm 0.7$ & $5.7 \pm 1.2$ & $9.5 \pm 2.8$ \\
\hline Progesterone $\left(\mathrm{ng} \mathrm{ml}^{-1}\right)$ & $49.2 \pm 3.0$ & $29.9 \pm 4.0^{*}$ & $38.5 \pm 5.2$ & $22.9 \pm 4.2^{*}$ & $24.3 \pm 4.2$ & $13.1 \pm 1.4$ \\
\hline IGF-I $\left(\mathrm{ng} \mathrm{ml}^{-1}\right)$ & $1725 \pm 155$ & $1096 \pm 204 *$ & $1002 \pm 155$ & $977 \pm 158$ & $892 \pm 71$ & $1292 \pm 258$ \\
\hline Corticosterone $\left(\mathrm{ng} \mathrm{m}^{-1}\right)$ & $325 \pm 74$ & $804 \pm 83^{*}$ & $408 \pm 58$ & $598 \pm 119$ & $403 \pm 80$ & $530 \pm 89$ \\
\hline \multicolumn{7}{|l|}{ Pups: } \\
\hline $\mathrm{T}_{3}\left(\mathrm{ng} \mathrm{dl} \mathrm{l}^{-1}\right)$ & $30.3 \pm 4.5$ & $43.5 \pm 8.5$ & $33.8 \pm 4.5$ & $48.8 \pm 4.4^{*}$ & $32.3 \pm 8.8$ & $32.0 \pm 6.3$ \\
\hline $\mathrm{T}_{4}\left(\mu \mathrm{g} \mathrm{dl^{-1 }}\right)$ & $6.9 \pm 0.3$ & $14.2 \pm 4.0^{*}$ & $7.4 \pm 0.2$ & $8.6 \pm 0.2^{*}$ & $7.1 \pm 0.1$ & $7.0 \pm 0.2$ \\
\hline Prolactin (ng ml-1) & $0.8 \pm 0.1$ & $1.2 \pm 0.4$ & $1.9 \pm 0.5$ & $1.2 \pm 0.4$ & $1.0 \pm 0.3$ & $2.6 \pm 0.5$ \\
\hline Growth hormone $\left(\mathrm{ng} \mathrm{ml}^{-1}\right)$ & $12.7 \pm 1.8$ & $26.3 \pm 5.0^{*}$ & $12.6 \pm 2.2$ & $11.7 \pm 2.4$ & $8.4 \pm 2.7$ & $6.4 \pm 0.9$ \\
\hline Body weight (g) & $14.71 \pm 0.70$ & $10.42 \pm 1.01^{*}$ & $25.74 \pm 0.67$ & $19.14 \pm 1.81^{*}$ & $39.60 \pm 1.74$ & $24.74 \pm 2.95^{*}$ \\
\hline Corticosterone (ng ml-1) & $4 \pm 2$ & $13 \pm 4$ & $26 \pm 4$ & $22 \pm 9$ & $154 \pm 24$ & $132 \pm 23$ \\
\hline
\end{tabular}

Values are means \pm SEM for groups of eight dams or eight litters.

${ }^{*} P<0.05$ compared with the respective control groups using one-way ANOVA and the Tukey's test.

$\mathrm{T}_{3}$ : triiodothyronine; $\mathrm{T}_{4}$ : tetraiodothyronine; IGF-I: insulin-like growth factor; $\mathrm{HT}$ : hyperthyroid.

$72^{\circ} \mathrm{C}$. The conditions were such that the amplification of the products was in the exponential phase and the assay was linear with respect to the amount of input RNA. RNA samples were assayed for DNA contamination by PCR without prior reverse transcription. The PCR products were analysed on $1.5 \%$ agarose gels containing $0.5 \mu$ g ethidium bromide $\mathrm{ml}^{-1}$ and photographed with a Polaroid camera. Band intensities of RT-PCR products were quantified using $\mathrm{NIH}$ Image software. Relative amounts of mRNA were expressed as the ratio of signal intensity for the target genes relative to that for ribosomal protein $\mathrm{L}_{19}$ cDNA.

\section{Statistical analyses}

Significant differences among means were considered at $P<0.05$ and identified by one-way ANOVA and Tukey's test. In all cases, the variances were homogeneous.

\section{Results}

\section{Serum concentrations of $T_{4}$ and $T_{3}$ in control and thyroxine-treated lactating rats and their pups}

Serum $\mathrm{T}_{4}$ and $\mathrm{T}_{3}$ concentrations in the $\mathrm{HT}$ lactating rats were significantly higher than those of control rats (Table 2).

Serum $T_{4}$ concentration of the pups from thyroxinetreated lactating dams was also significantly higher compared with offspring of control lactating dams on day 7 and day 14 of neonatal life, but not on day 21. Serum $T_{3}$ concentrations were significantly higher on day 14 compared with the pups from the control lactating dams, but no differences were observed on day 7 and day 21 (Table 2).

The $T_{4}$ treatment did not affect weight gain of or food 
Table 3. Effects of hyperthyroidism on prolactin binding in the mammary gland and liver from lactating rats and their pups

\begin{tabular}{|c|c|c|c|c|c|c|}
\hline & \multicolumn{2}{|c|}{ Day 7 of lactation } & \multicolumn{2}{|c|}{ Day 14 of lactation } & \multicolumn{2}{|c|}{ Day 21 of lactation } \\
\hline & Control & $\mathrm{HT}$ & Control & $\mathrm{HT}$ & Control & $\mathrm{HT}$ \\
\hline \multicolumn{7}{|l|}{ Mothers: } \\
\hline $\begin{array}{l}\text { Mammary prolactin binding } \\
\text { (c.p.m. }{ }^{125} \text { I-labelled } \\
\text { prolactin } \mathrm{mg}^{-1} \text { protein) }\end{array}$ & $8506 \pm 1473$ & $7327 \pm 1052$ & $7778 \pm 977$ & $9796 \pm 1115$ & $4187 \pm 526$ & $4471 \pm 884$ \\
\hline $\begin{array}{l}\text { Liver prolactin binding } \\
\text { (c.p.m. }{ }^{125} \text {-labelled } \\
\text { prolactin } \text { mg }^{-1} \text { protein) }\end{array}$ & $13789 \pm 1310$ & $14045 \pm 2160$ & $6175 \pm 651$ & $11924 \pm 1928^{*}$ & $7420 \pm 1400$ & $7634 \pm 1655$ \\
\hline \multicolumn{7}{|l|}{ Pups: } \\
\hline $\begin{array}{l}\text { Liver prolactin binding } \\
\text { (c.p.m. }{ }^{125} \text {-labelled } \\
\text { prolactin } \mathrm{mg}^{-1} \text { protein) }\end{array}$ & $6199 \pm 769$ & $4343 \pm 750$ & $3951 \pm 656$ & $3960 \pm 963$ & $11027 \pm 1394$ & $13146 \pm 1019$ \\
\hline
\end{tabular}

Values are means \pm SEM for groups of eight dams or eight litters.

${ }^{*} P<0.05$ compared with the respective control groups using one-way ANOVA and the Tukey's test.

HT: hyperthyroidism.

intake by the mothers, but mean weight increase of the pups from the HT dams was significantly lower than for control pups for the 3 days of lactation studied (Table 2).

In contrast to another study in which a higher daily dose of $\mathrm{T}_{4}$ was used (Rosato et al., 1992b), the thyroxine-treated mothers had normal maternal behaviour, and the pups were clean, warm and well cared for by the mothers at all times, and the mothers nursed readily, showing no differences from the control mothers.

Serum concentrations of prolactin, progesterone, growth hormone, IGF-I and corticosterone in control and thyroxine-treated lactating rats and their pups

Serum prolactin concentrations decreased progressively during lactation in both control and thyroxine-treated rats, and reached very low concentrations on day 21 (Table 2). Circulating serum prolactin concentrations were significantly lower in HT mothers compared with the control mothers despite continuous suckling on day 7 and day 14 of lactation, but there were no differences on day 21 (Table 2). In contrast, serum growth hormone concentrations of the thyroxine-treated and control mothers were not different (Table 2). Circulating concentrations of IGF-I were high on day 7 in control rats and diminished on subsequent days. In thyroxine-treated mothers, serum concentrations of IGF-I were significantly lower than in control mothers on day 7 , but there were no differences on day 14 and day 21 of lactation (Table 2).

Production of progesterone by the corpora lutea resulting from the postpartum ovulation resulted in high serum progesterone concentrations in the control rats on day 7 , which decreased gradually during lactation, in an approximately parallel manner to circulating prolactin, but progesterone concentrations always remained higher than typical values of dioestrous rats. Concentrations of circulating progesterone in the thyroxine-treated rats were also high on day 7 and day 14 of lactation, but the concentrations were always lower compared with the control group (Table 2).

Circulating concentrations of corticosterone did not vary during lactation in the control rats, but were significantly increased on day 7 in the thyroxine-treated mothers (Table 2).

Circulating concentrations of prolactin were low in the pups and did not change during lactation or in control pups and pups of thyroxine-treated mothers (Table 2). Serum concentrations of growth hormone in the control pups did not differ during the 3 days of lactation studied, but were significantly higher in the pups from thyroxine-treated mothers on day 7 (Table 2). Serum concentrations of corticosterone increased markedly from day 7 to day 21 after birth, and there were no differences between the control pups and pups of thyroxine-treated dams (Table 2).

\section{Prolactin binding sites in mammary glands and livers of lactating thyroxine-treated and control rats and their pups}

Prolactin binding in the maternal mammary glands was comparable in thyroxine-treated and control rats and was decreased on day 21 of lactation compared with day 7 and day 14 (Table 3). Prolactin binding in the liver decreased earlier: on day 14 in the control rats, and on day 21 in the thyroxine-treated mothers, resulting in significantly higher binding on day 14 (Table 3 ).

Liver prolactin binding in the pups increased on day 21 compared with day 7 and day 14, and there was no difference between control pups and pups from thyroxinetreated mothers (Table 3).

Serum prolactin, growth hormone and oxytocin response to acute suckling in control and thyroxine-treated lactating rats

An acute suckling experiment was performed to allow the pups to suckle for $30 \mathrm{~min}$ after an $8 \mathrm{~h}$ separation from 
(a)

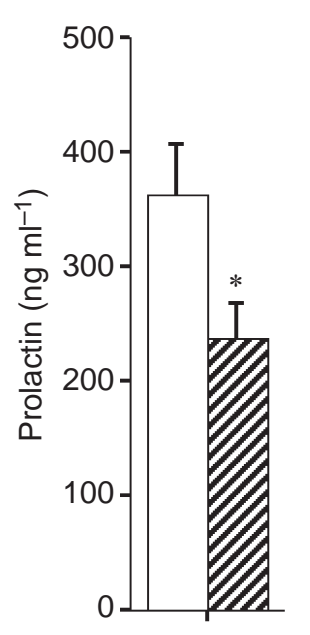

(b)

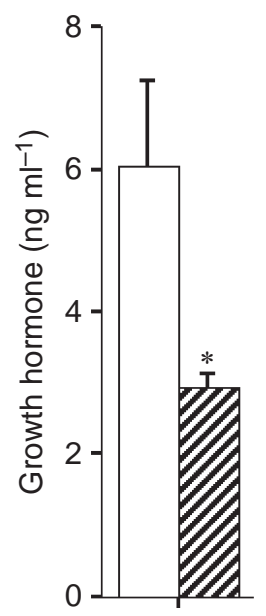

(c)

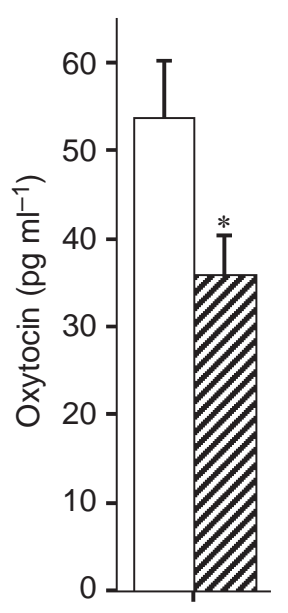

(d)

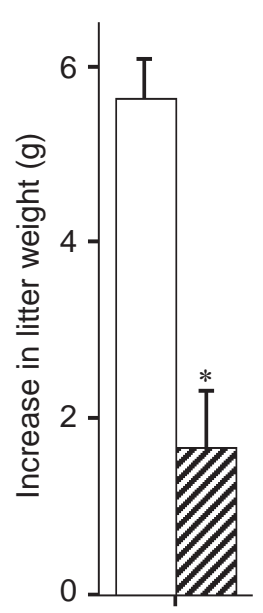

Fig. 1. Effect of $30 \mathrm{~min}$ of suckling after $8 \mathrm{~h}$ separation of mother and pups on the serum concentrations of (a) prolactin, (b) growth hormone and (c) oxytocin, and on (d) milk ejection (estimated by the change in litter weight after the 30 min suckling period) in (10-11 days post partum) control $(\square)$ or thyroxine-treated $(\boldsymbol{U})$ rats in mid-lactation. Values are means \pm SEM for groups of eight dams or eight litters; ${ }^{*} P<0.05$ compared with the respective control groups using one-way ANOVA and the $t$ test.

their mothers to determine whether the decreased circulating concentrations of prolactin and the decreased growth rate of the litters were related to an impairment in the response to suckling. There was a significantly smaller increase in serum prolactin and oxytocin concentrations after 30 min of suckling in thyroxine-treated rats compared with control rats (Fig. 1). Serum concentrations of growth hormone were also lower in the thyroxine-treated mothers. In concordance with the decrease in oxytocin concentrations, the quantity of milk obtained by pups from thyroxine-treated mothers was significantly lower compared with the controls, indicating impairment in milk ejection (Fig. 1). The decreased response observed in the thyroxine-treated mothers could not be the consequence of less suckling by their pups, as they attached themselves readily to the nipples and suckled vigorously during the 30 min test period. Most of the pups were still attached to the nipples when the mothers were removed for collection of blood samples. All the nipples showed signs of recent and intense suckling and the pups from thyroxine-treated mothers, although smaller than control pups, were very active. In these respects, there were no differences between the control litters and litters from thyroxine-treated mothers or in the behaviour of the mothers during the $30 \mathrm{~min}$ suckling period.

\section{Mammary gland function in control and thyroxine- treated lactating rats}

Mammary gland concentrations of casein (thyroxinetreated: $8.05 \pm 1.68$ versus control: $8.61 \pm 1.56 \mu \mathrm{g} \mathrm{mg} \mathrm{l}{ }^{-1}$ tissue), lactose (thyroxine-treated: $8.28 \pm 1.08$ versus

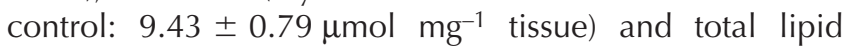
(thyroxine-treated: $128.2 \pm 3.2$ versus control: $119.2 \pm$ $11.4 \mathrm{mg} \mathrm{g}^{-1}$ tissue) on day 14 of lactation were similar in control and thyroxine-treated mothers.

Histological examination of the mammary gland was performed on days 7, 14 and 21 of lactation. Control glands on the 3 days of lactation showed mostly distended alveoli, with abundant signs of secretion in the lumina, indicative of an active secretory state (Fig. 2). The proportion of epithelial versus adipose tissue in the thyroxine-treated rats was greater on day 7 and lower on day 14 and day 21 in comparison with the control rats, indicating initiation of a process of mammary remodelling. On day 7 , the thyroxinetreated rats showed fully distended alveoli comparable to those of the control rats, but on day 14 many alveoli in the thyroxine-treated rats had fewer or no signs of intraluminal secretion. On day 21, an important proportion of the alveoli also showed diminished or no secretion in the lumina and many of the nuclei in the alveolar cells were small and densely stained. This characteristic is one of the typical histological features of apoptotic cells. Although the reduction in size of alveolar lumina may be a consequence of increased mammary evacuation by suckling, the other features are indicative of precocious involution in the mammary glands of the thyroxine-treated mothers.

The accelerated mammary involution in the HT rats was confirmed by investigating the activation of programmed cell death mechanisms, detecting apoptotic nuclei in mammary histological preparation by means of the TUNEL reaction. On day 14 of lactation there were relatively few 
(a)

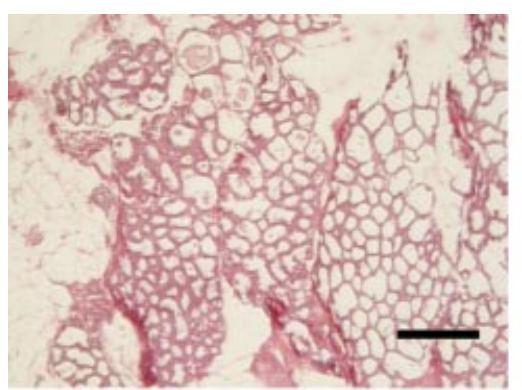

(b)

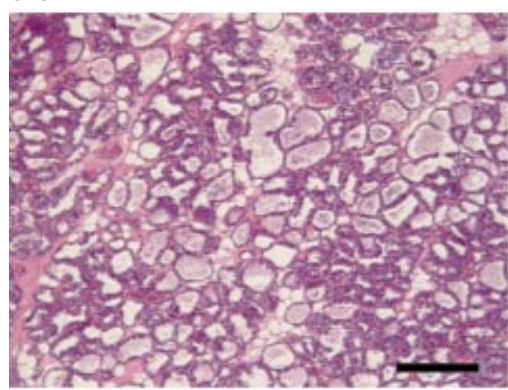

(c)

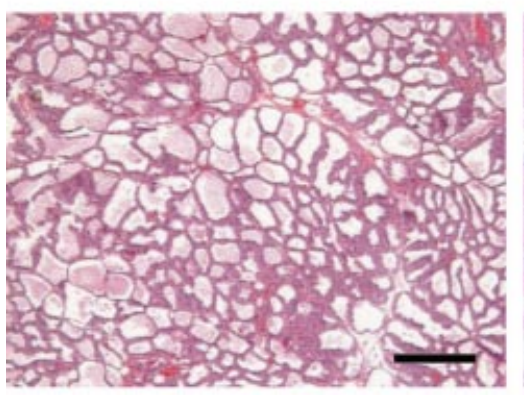

Day 7 of lactation

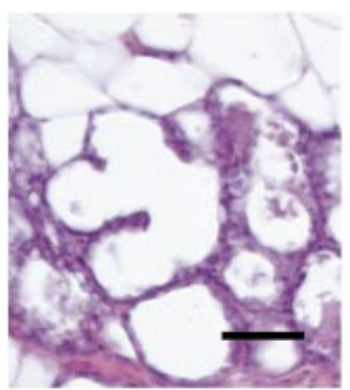

Day 14 of lactation
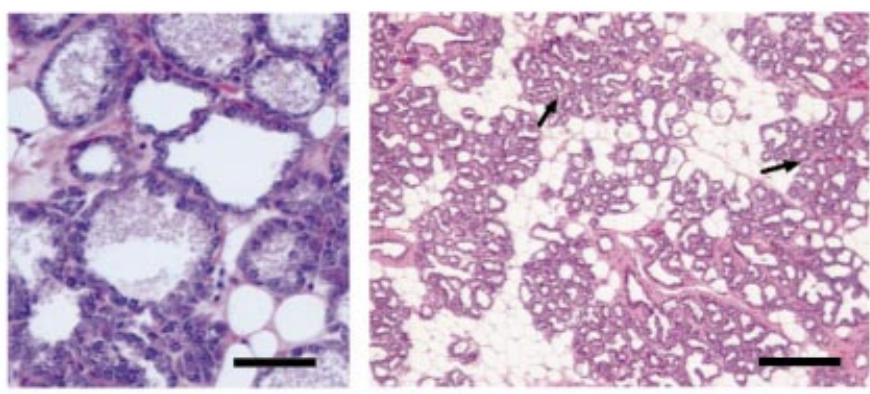

Day 21 of lactation

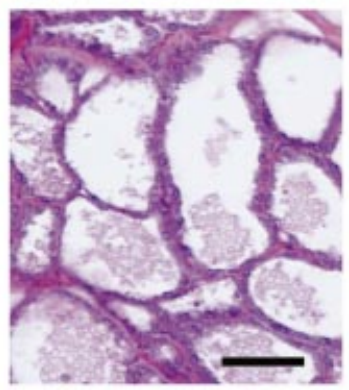

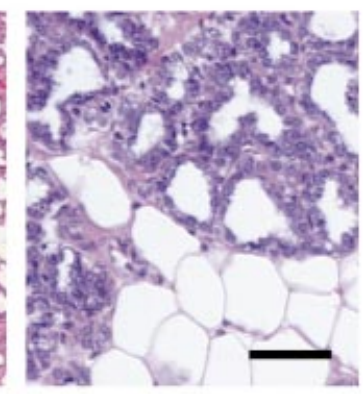

HT

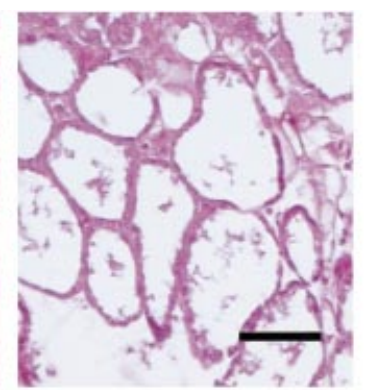

E.

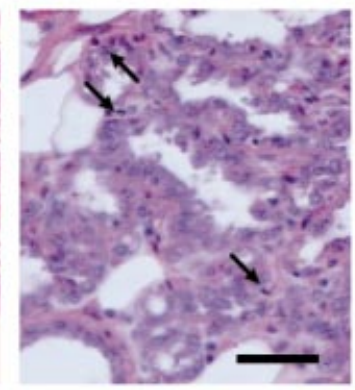

Fig. 2. Histology of mammary glands of hyperthyroid and control lactating rats. Mammary glands from rats at days (a) 7 , (b) 14 and (c) 21 of lactation were fixed and stained with haematoxylin-eosin. The images were obtained at $\times 100$ (left section of each image) and $\times 400$ magnifications (right section of each image). On day 14 and day 21 of lactation the hyperthyroid mothers showed an increased number of adipocytes and a greater proportion of alveoli with reduced lumen (arrows on $\times 100$ images). On day 21 of lactation there were numerous small and densely stained nuclei (arrows on the $\times 400$ image) in the hyperthyroid mothers. The scale bars represent $100 \mu \mathrm{m}$ for images at $\times 100$ magnification and $25 \mu \mathrm{m}$ for images at $\times 400$ magnification.

apoptotic nuclei in the alveolar epithelial cells in controls and thyroxine-treated rats (Fig. 3). However, on day 21, there was a marked increase in the number of apoptotic nuclei in the hyperthyroid glands with respect to day 14 or to the controls, indicative of a premature mammary involution.

\section{Expression of $S G P_{2}, I G F-I, I G F B P 5$ and $B C L-2$ in the mammary gland in control and thyroxine-treated lactating rats}

Gene expression of several proteins related to mammary cell survival or programmed death, namely SGP-2, Bcl-2 and IGF-I as promoters of cell survival and IGFBP-5 as proapoptotic factor, were determined to continue investigating the activation of precocious mammary involution on the mammary glands of the thyroxine-treated mothers. As the expression of SGP-2 gene is induced during the involution of the mammary gland (French et al., 1996; Lund et al., 1996), the relative expression of its mRNA in mammary tissues by RT-PCR was examined from day 14 to day 21 of lactation. SGP2 mRNA increased significantly from day 14 to day 21 in both groups of rats, but was also significantly higher on the mammary glands of the thyroxine-treated rats on both days (Fig. 4a). Although it is well known that Bcl-2 promotes cell survival and inhibits apoptosis, there were no significant changes in its expression, as measured by RTPCR, on mammary tissues from day 14 to day 21 of lactation in the control and thyroxine-treated rats (Fig. 4b).

IGF-I expression was abundant in control rats on day 14 , but was hardly detectable on day 21 (Fig. 5). In the thyroxine-treated rats, the relative expression of IGF-I on 
(a)
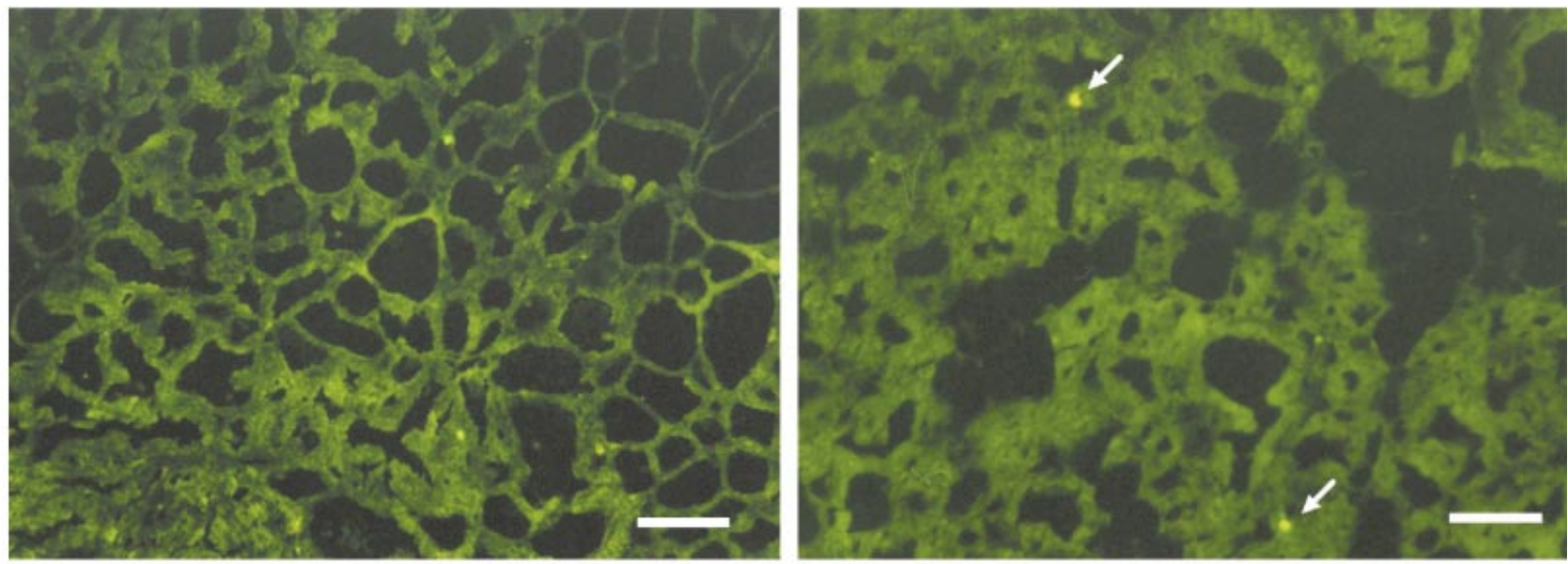

(b)

Control

Day 21 of lactation

Hyperthyroid
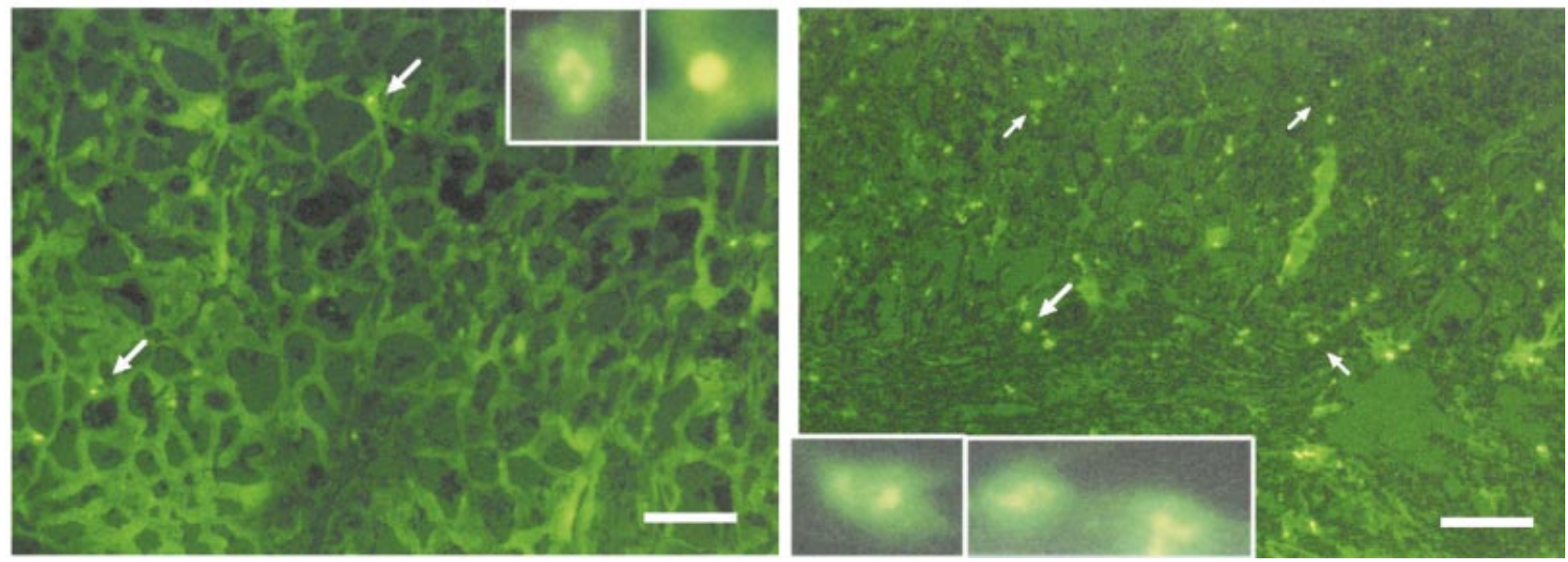

Fig. 3. Detection of apoptotic nuclei in mammary sections of control and hyperthyroid rats on (a) day 14 and (b) day 21 of lactation by TdT-mediated dUTP nick-end labelling (TUNEL). Sections were photographed under a fluorescence microscope at $\times 100$ and $\times 250$ (insets) magnifications. In the hyperthyroid mothers on day 14 of lactation and in the controls on both day 14 and day 21 there are very few apoptotic nuclei, whereas on day 21 of lactation many apoptotic nuclei (white arrows) are present in the lobulo-alveolar cells. Scale bars represent $100 \mu \mathrm{m}$ for images at $\times 100$ magnification and $40 \mu \mathrm{m}$ for insets at $\times 250$ magnification.

day 21 was similar to that of day 14 , and was significantly higher than in the control rats (Fig. 5b). In contrast, no changes were observed in relative expression of IGFBP-5 (Fig. 5d).

\section{Discussion}

The present study describes the significant effects of a moderate hyperthyroid state on the course of lactation and on mammary gland function in rats, which resulted in stunted growth of the litters. The dose of $10 \mu \mathrm{g} \mathrm{T}_{4}$ per $100 \mathrm{~g}$ body weight induced an increase in serum concentrations of $\mathrm{T}_{3}$ and $\mathrm{T}_{4}$ in the dams at the three timepoints of lactation studied, thus confirming the state of hyperthyroidism.

Lactation is under multi-hormonal control and requires the presence of prolactin, insulin, glucocorticoids, growth hormone and a variety of growth factors (Bole-Feysot et al., 1998). Hyperthyroidism resulted in a decrease in serum prolactin on day 7 and day 14 of lactation despite active and vigorous suckling by the pups. An acute suckling experiment, which showed decreased response to suckling in prolactin, growth hormone and oxytocin secretion and in milk ejection in the thyroxine-treated mothers, indicated that this decrease was provoked by impairments in the suckling reflex. Thus, prolactin and oxytocin secretion of thyroxine-treated rats was reduced during lactation, most probably due to interference in the suckling neural pathway. It has been shown that hyperthyroidism decreases oxytocin mRNA in the hypothalamus, most probably by affecting oestrogen action (Dellovade et al., 1999). Excess 
(a)

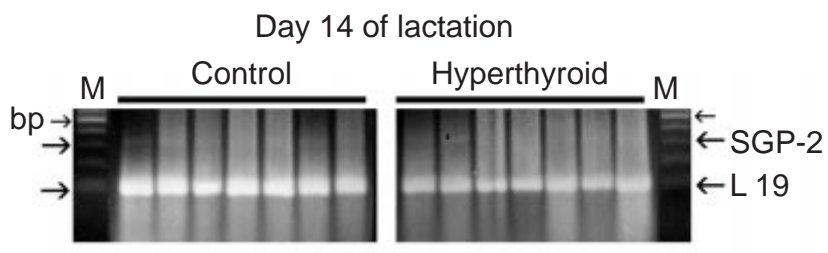

Day 21 of lactation

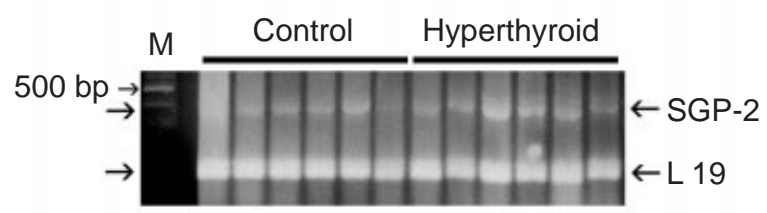

(c)

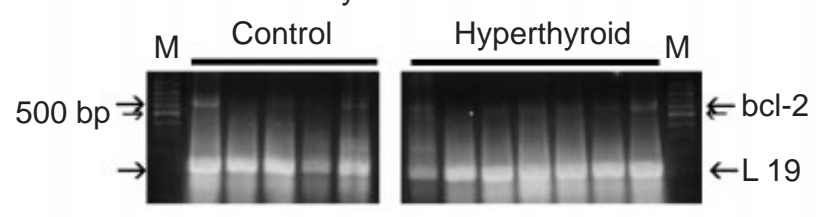

Day 21 of lactation

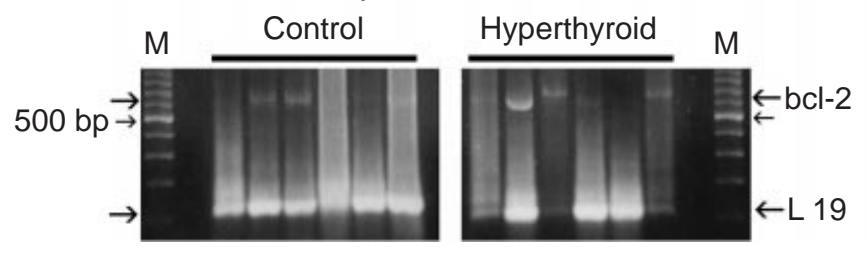

(b)

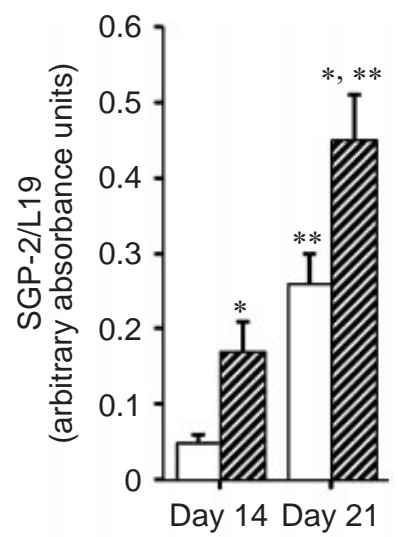

(d)

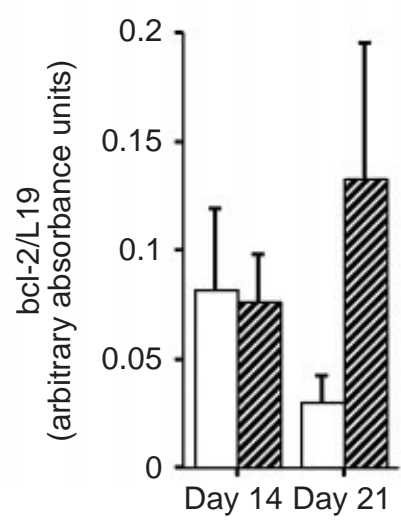

Fig. 4. Measurement by RT-PCR of expression of (a,b) SGP-2 and (c,d) Bcl-2mRNAs from mammary glands of control $(\square)$ and thyroxine-treated $(\boldsymbol{Z})$ rats on day 14 and day 21 of lactation. Ethidium bromide fluorescence photographs of the gel electrophoresis of the amplification products of (a) SGP-2 or (c) Bcl-2, respectively, co-amplified with L19 as internal control; Lane M: molecular weight markers. Relative expression of (b) SGP-2 or (d) Bcl-2 relative to L19. The gel photographs were quantified using NIH Image and expressed as arbitrary units. Results are the average \pm SEM of six determinations per group. ${ }^{*} P<0.05$ compared with the respective control groups using one-way ANOVA and the $t$ test; ${ }^{* *} P<0.05$ compared with the respective day 14 group using one-way ANOVA and the $t$ test.

thyroid hormone may also interfere with the regulation of prolactin release, perhaps by inhibiting the release of thyrotrophin releasing hormone $(\mathrm{TRH})$. TRH seems to be involved in prolactin release during lactation. Hypothalamic TRH mRNA and peptide increase during early and mid-lactation, respectively, and after acute suckling (van Haasteren et al., 1996), whereas passive immunization against TRH reduces the suckling induced prolactin release (van Haasteren et al., 1996). Although TRH may not be the only contributor to suckling induced prolactin release, the continuous inhibitory action of the high concentrations of thyroid hormones on TRH may have contributed to the reduced serum prolactin concentrations observed during lactation or after suckling. The increased circulating concentrations of corticosterone observed in early lactation may also have interfered with prolactin release in the thyroxine-treated lactating rats, as corticosterone interferes with prolactin release in suckled or non-suckled lactating rats (de Greef et al., 1987). In concordance with the decreased oxytocin concentrations, milk ejection was reduced, as shown by the inability of the pups to obtain adequate amounts of milk after the acute suckling stimulus. The stimulatory effect of oxytocin on milk secretion is mainly accounted for by its role in the milk ejection reflex. The decrease in milk secretion and ejection could be one of the causes of the reduction in the growth rate of the litters from thyroxine-treated rats, associated with other effects of the thyroid hormones. 
(b)

(a)

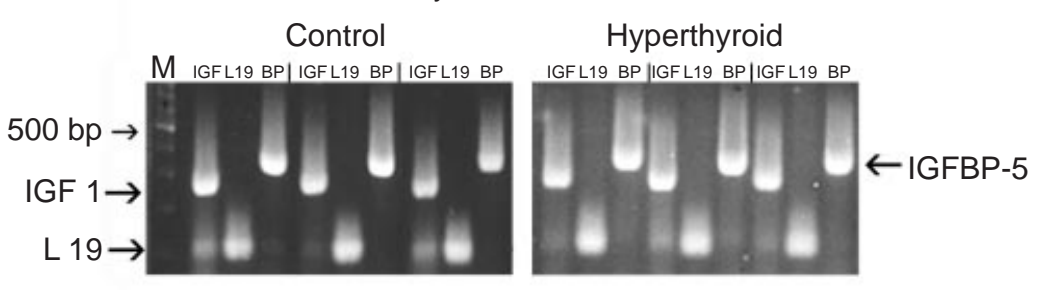

(c)

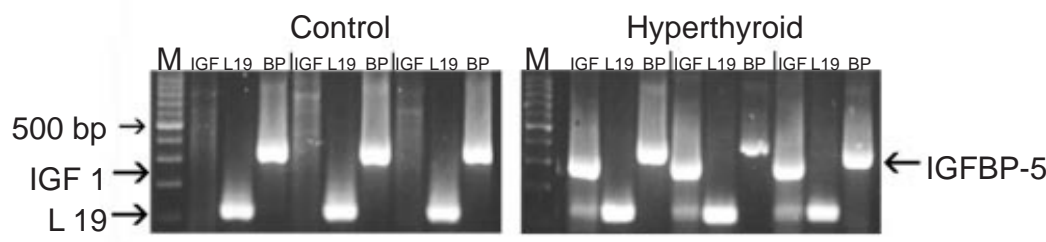

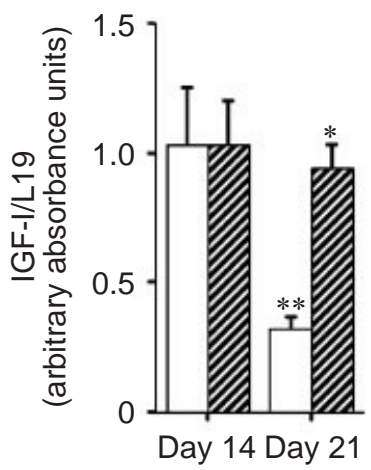

(d)

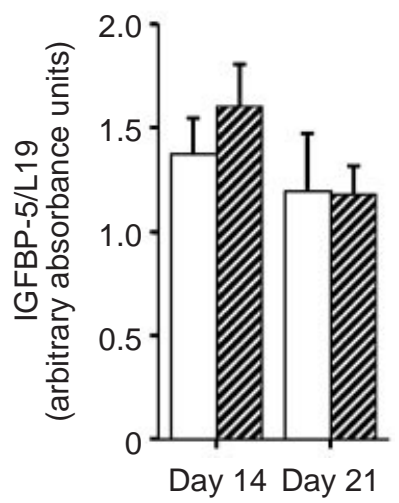

Fig. 5. Measurement by RT-PCR of expression of (a,b) insulin-like growth factor 1 (IGF-I) and (c,d) insulin-like growth factor binding protein 5 (IGFBP-5) mRNAs from mammary glands of control ( $\square$ ) and thyroxine-treated ( $)$ mothers on day 14 and day 21 of lactation. Ethidium bromide fluorescence photograph of the gel electrophoresis of the amplification products of (a) IGF-I and (c) IGFBP-5 and L19 as retrotranscription control; Lane M: molecular weight markers; Lane IGF: IGF-I amplification product; Lane BP: IGFBP-5 amplification product; L19: L19 amplification product. Relative expression of (b) IGF-I and (d) IGFBP-5 relative to L19, respectively. The gel photographs were quantified using NIH Image and expressed as arbitrary units. Results are the average \pm SEM of six determinations per group. ${ }^{*} P<0.05$ compared with the respective control groups using one-way ANOVA and the $t$ test; ${ }^{* *} P<0.05$ compared with the respective day 14 group using one-way ANOVA and the $t$ test.

Postpartum ovulation seems to have occurred in both groups of rats, as circulating progesterone concentrations were increased on day 7 and day 14 , reaching concentrations higher than those typical of inactive corpora lutea, such as in oestrus or early dioestrus (about $10 \mathrm{ng} \mathrm{m}^{-1}$ ). However, luteal function of the thyroxine-treated rats seemed to have decreased and may have resulted in premature luteal failure, as indicated by lower circulating progesterone concentrations than the controls. Because prolactin is the main luteotrophic hormone during lactation in rats, the lower circulating concentrations of progesterone is a good indicator of sustained decrease in prolactin secretion during lactation in the thyroxine-treated rats.

Several other studies (Feng et al., 1995; Flint et al., 2000; Berg et al., 2002) show that prolactin, corticosterone, growth hormone and progesterone maintain mammary gland function and milk secretion, at least in part, by inhibiting programmed cell death or apoptosis. Growth hormone acts by increasing IGF-I synthesis, and prolactin represses IGFBP-5 synthesis, thus maximising the effect of IGF-I on mammary epithelial cell survival. In addition, chronic hyperthyroidism decreases growth hormone concentration in late pregnancy in rats injected with $25 \mu \mathrm{g} \mathrm{T}$ per 100 g body weight (Rosato et al., 1998). Changes in serum growth hormone concentrations were not observed in the lactating hyperthyroid dams compared with the controls, but growth hormone concentrations after $30 \mathrm{~min}$ of acute suckling were slightly lower in the thyroxinetreated rats. The decrease in prolactin concentrations during lactation, along with the unchanged or slightly lowered growth hormone concentrations and the impaired oxytocin response to suckling, may be responsible for the signs of premature involution of the mammary tissue in the thyroxine-treated rats. In addition, a significant diminution in circulating IGF-I was observed in the thyroxine-treated mothers on day 7 of lactation. Neuenschwander et al. 
(1996) showed in a transgenic mouse model that IGF-I has anti-apoptotic properties and inhibits the involution of the mammary gland. Thus, the decreased circulating concentrations of IGF-I on day 7 of lactation in the thyroxine-treated mothers may be instrumental in the signs of precocious involution of the mammary tissue observed on day 14 and day 21 (by the increase in SGP-2 expression and the increased TUNEL positive cells on day 21). However, the increased corticosterone concentrations on day 7 may have acted as a protective factor during early lactation. The maintenance of mammary expression of IGF-I on day 21 in amounts similar to those of day 14 in the thyroxine-treated mothers may also have acted as a protective factor during late lactation, thus limiting the progress of involution. These anti-apoptotic effects could be related to the presence of the suckling stimulus, as it is known that continuous suckling protects lobulo alveolar structure, preventing the start of programmed cell death ( $\mathrm{Li}$ et al., 1997).

Mammary involution induced by weaning or any interruption in milk secretion appears to proceed in two distinct stages (Li et al., 1997; Furth, 1999; Marti et al., 1999). The first stage initiated shortly after the interruption of suckling is characterized by accumulation of milk, apoptosis of epithelial cells and changes in the expression of several genes, including milk proteins and SGP-2. This stage is reversible if suckling is reinitiated within 36-48 h ( $\mathrm{Li}$ et al., 1997; Marti et al., 1999). The second stage, initiated 3-5 days after weaning, is not reversible and characterized by extensive degradation of basement membrane and remodelling of mammary architecture to a more virgin-like state with predominance of adipose over epithelial tissue. On day 7 of lactation, mammary histology showed images of full lactation in the thyroxine-treated rats with a reduced proportion of adipose tissue similar to control rats. However, by day 14 in thyroxine-treated rats we found increases in SGP-2 and on day 21 increased epithelial cell apoptosis indicative of stage I involution, both accompanied with increased adipose tissue in the presence of active suckling that seemed to maintain milk synthesis. It is probably likely that the decrease in circulating prolactin and progesterone observed at early and mid-lactation were instrumental in inducing these signs of involution in the thyroxine-treated rats.

The control rats also seemed to be in the early stages of mammary involution by day 21 of lactation, as indicated by the increase in SGP-2 and the decrease in the expression of IGF-I, the survival factor, although there were no other outward signs of involution. Mammary involution in control rats was not apparent at day 14 of lactation. Surprisingly, there were no changes in the expression of IGFBP-5, even though the expression of IGFBP-5 is repressed by high prolactin concentrations (Tonner et al., 1997), or on Bcl-2 expression, which showed only a non-significant tendency to increase on day 21 in the thyroxine-treated rats. IGFBP-5 expression was expected to increase concomitantly with the decrease in circulating prolactin in the thyroxine-treated rats.
Thyroxine-treated rats in mid-lactation may be in a state in which involution signals (milk stasis produced by impaired oxytocin secretion and early decrease in circulating IGF-I) coexist with survival signals (continuous suckling stimulus, high circulating concentrations of corticosterone at early lactation and increased mammary IGF-I mRNA concentrations on day 21), possibly resulting in a phase 1 stage of involution, namely increased apoptotic cell death in a mammary gland that is otherwise actively secreting milk.

As prolactin upregulates its own receptor in some tissues, the binding of prolactin in mammary glands and livers was analysed. In contrast to the decrease in serum prolactin, there were no effects of hyperthyroidism on the number of binding sites for prolactin in the mammary gland, but the decrease in prolactin binding on day 21 in both groups may be related to the initiation of mammary involution. Liver prolactin binding decreased between the initiation and end of lactation (Jahn et al., 1991), but the decrease was delayed in the thyroxine-treated rats. In lactating rats, the expression of the prolactin receptor in the liver decreases to minimal amounts, whereas in the mammary gland expression is increased (Jahn et al., 1991). The maintenance of higher liver prolactin receptor concentration in the thyroxinetreated rats indicates that prolactin exerts different metabolic actions during the hyperthyroid state, and could contribute to the diminution in circulating prolactin, due to increased metabolism of prolactin by the liver.

The pups were mildly hyperthyroid (day 14) and despite diminished growth, they had increased circulating concentrations of growth hormone on day 7 , most probably a consequence of hyperthyroidism per se. In rats, thyroid hormones affect postnatal growth after days 12-14 of age (at this age, plasma $T_{3}$ concentrations have reached a maximum value), 11 days earlier than the appearance of the influence of growth hormone (Cabello and Wrutniak, 1989). The association of the hyperthyroid state of the pups along with the defective mammary function and impaired milk ejection reflex may be directly responsible for their diminished growth rate.

The results of the present study may have clinical relevance in the management of mild hyperthyroidism in the puerperium when the mothers wish to nurse their infant. Recent reports have shown a direct association between thyroid disorders and breast cancer (Smyth, 1997). It is known that a decrease in the frequency of programmed cell death increases tumour size and increasing the apoptotic rate is a therapeutic goal for many cancer chemotherapies. The study of the effects of hyperthyroidism on mammary gland development and involution could lead to significant applications in the prevention or control of breast neoplasia.

The authors express their thanks to R. P. Deis for critical comments on the manuscript. This work has been supported by grants 4139, PIP 0826 from CONICET (National Investigation Council of Science and Technology, Argentina), PICT-PMT 01930, 
06877 and 0441 from the FONCYT and Project 8104 from San Luis University, Argentina. The authors are indebted to A. F. Parlow from the NHPP for gift of the prolactin and growth hormone radioimmunoassay kits and to D. Gardella de Rodriguez, Glaxo, Argentina, for the gift of $\mathrm{T}_{4}$.

\section{References}

Berg MN, Dharmarajan AM and Waddell BJ (2002) Glucocorticoids and progesterone prevent apoptosis in the lactating rat mammary gland Endocrinology $143222-227$

Bole-Feysot C, Goffin V, Edery M, Binart N and Kelly PA (1988) Prolactin and its receptor: actions, signal transduction pathways and phenotypes observed in prolactin receptor knockout mice Endocrine Reviews 19 225-268

Bussmann LE and Deis RP (1979) Studies concerning the hormonal induction of lactogenesis by prostaglandin $\mathrm{F}_{2 \alpha}$ in pregnant rats Journal of Steroid Biochemistry 11 1485-1489

Bussmann LE and Deis RP (1984) Hormonal regulation of casein synthesis at the end of pregnancy Molecular and Cellular Endocrinology 39 $115-118$

Cabello G and Wrutniak C (1989) Thyroid hormone and growth: relationships with growth hormone effects and regulation Reproduction, Nutrition and Development 29 387-402

Chomczynski P and Sacchi N (1987) Single-step method of RNA isolation by acid guanidinium thiocyanate-phenol-chloroform extraction Analytical Biochemistry $\mathbf{1 6 2} 156-159$

de Greef WJ, Voogt JL, Visser TJ, Lamberts SW and van der Schoot P (1987) Control of prolactin release induced by suckling Endocrinology 121 316-322

Dellovade TL, Zhu YS and Pfaff DW (1999) Thyroid hormones and estrogen affect oxytocin gene expression in hypothalamic neurons Journal of Neuroendocrinology 11 1-10

Edery M, Houdebine LM, Djiane J and Kelly PA (1984) Studies of betacasein content of normal and neoplastic rat mammary tissues by a homologous radioimmunoassay Molecular and Cellular Endocrinology 34 145-151

Feng Z, Marti A, Jehn B, Altermatt HJ, Chicaiza G and Jaggi R (1995) Glucocorticoid and progesterone inhibit involution and programmed cell death in the mouse mammary gland Journal of Cell Biology 131 1095-1103

Flint DJ, Tonner E and Allan GJ (2000) Insulin-like growth factor binding proteins: IGF-dependent and independent effects in the mammary gland Journal of Mammary Gland Biology and Neoplasia 5 65-73

Folch J, Less M and Sloane-Stanley GH (1968) A simple method for the isolation and purification of total lipid from animal tissues Journal of Biological Chemistry 226 497-509

French LE, Soriano JV, Montesano R and Pepper MS (1996) Modulation of clusterin gene expression in the rat mammary gland during pregnancy, lactation and involution Biology of Reproduction 55 1213-1220

Furth PA (1999) Introduction: mammary gland involution and apoptosis of mammary epithelial cells Journal of Mammary Gland Biology and Neoplasia 4 123-127

Imagawa W, Yang J, Guzman R and Nandi A (1994) Control of mammary gland development. In The Physiology of Reproduction pp 1033-1063 Eds E Knobil and JD Neill. Raven Press, New York

Jahn GA and Deis RP (1991) The involvement of the adrenergic system on the release of prolactin and lactogenesis at the end of pregnancy in the rat Journal of Endocrinology 129 343-350

Jahn GA, Edery M, Belair L, Kelly PA and Djiane J (1991) Prolactin receptor gene expression in rat mammary gland and liver during pregnancy and lactation Endocrinology 128 2976-2984

Jahn GA, Moya G, Jammes H and Rosato RR (1995) Effect of chronic thyroid hormone treatment on cycling, ovulation, serum reproductive hormones and ovarian $\mathrm{LH}$ and prolactin receptors in rats Endocrine 3 $121-127$
Katoh M, Raguet S, Zachwieja J, Djiane J and Kelly PA (1987) Hepatic prolactin receptors in the rat: characterization using monoclonal antireceptor antibodies Endocrinology 120 739-749

Kuhn NJ and Lowenstein JM (1967) Lactogenesis in the rat changes in metabolic parameters at parturition Biochemical Journal 105 995-1002

Li M, Liu X, Robinson G, Bar-Peled U, Wagner KU, Young WS, Henninghausen L and Furth PA (1997) Mammary-derived signals activate programmed cell death during the first stage of mammary gland involution Proceedings National Academy of Sciences 94 3425-3430

Lowry OH, Rosebrough NJ, Farr AL and Randal RJ (1951) Protein measured with the Folin-phenol reagent Journal of Biological Chemistry 193 265-275

Lund LR, Romer J, Thomasset N, Solverg H, Pyke C, Bissell MJ, Dano K and Werb Z (1996) Two distinct phases of apoptosis in mammary gland involution: proteinase-independent and -dependent pathways Development 122 181-193

Marti A, Jaggi R, Vallan C, Ritter PM, Baltzer A, Srinivasan A, Dharmarajan AM and Friss RR (1999) Physiological apoptosis in hormone-dependent tissues: involvement of caspases Cell Death and Differentiation 6 1190-1200

Neuenschwander S, Schwartz A, Wood TL, Roberts CTJ, Henninghausen L and LeRoith D (1996) Involution of the lactating mammary gland is inhibited by the IGF system in a transgenic mouse model Journal of Clinical Investigation 97 2225-2232

Puissant C and Houdebine L-M (1990) An improvement of the single-step method of RNA isolation by acid guanidinium thiocyanate-phenolchloroform extraction Biotechniques 8 148-149

Quarrie LH, Addey CVP and Wilde CJ (1996) Programmed cell death during mammary tissue involution induced by weaning, litter removal and milk stasis Journal of Cell Physiology 168 559-569

Rodin A and Rodin A (1989) Thyroid disease in pregnancy British Journal of Hospital Medicine 41 234-242

Rosato RR, Jahn GA and Gimenez MS (1992a) Amelioration of some metabolic effects produced by hyperthyroidism in late pregnant rats and their fetuses: effects on lipids and proteins Hormone Metabolic Research 24 15-20

Rosato RR, Gimenez MS and Jahn GA (1992b) Effects of chronic thyroid hormone administration on pregnancy, lactogenesis and lactation in the rat Acta Endocrinologica 127 547-554

Rosato RR, Jammes H and Jahn GA (1998) Effect of chronic thyroxine treatment on pregnancy in rats: effects on oestrogen, progesterone, prolactin and $\mathrm{GH}$ receptors in uterus, liver and mammary gland Endocrine Research 24 269-284

Schorr K, Li M, Bar-Peled U et al. (1999) Gain of Bcl-2 is more potent than bax loss in regulating mammary epithelial cell survival in vivo. Cancer Research 59 2541-2545

Smyth PP (1997) The thyroid and breast cancer: a significant association? Annals of Medicine 29 189-191

Tonner E, Barber MC, Travers MT, Logan A and Flint DJ (1997) Hormonal control of insulin-like growth factor-binding protein-5 production in the involuting mammary gland of the rat Endocrinology 138 5101-5107

Travers MT, Barber MC, Tonner E, Quarrie L, Wilde CJ and Flint DJ (1996) The role of prolactin and growth hormone in the regulation of casein gene expression and mammary cell survival: relationships to milk synthesis and secretion Endocrinology 137 1530-1539

van Haasteren GA, van Toor H, Klootwijk W et al. (1996) Studies on the role of TRH and corticosterone in the regulation of prolactin and thyrotrophin secretion during lactation Journal of Endocrinology 148 325-336

Varas SM, Jahn GA and Giménez MS (2001) Hyperthyroidism affects lipid metabolism in lactating and suckling rats Lipids $\mathbf{3 6} 801-806$

Received 30 April 2002.

First decision 3 July 2002

Revised manuscript received 22 July 2002.

Accepted 23 July 2002. 